\title{
Relationship Between Hygienic Behavior and Varroa destructor Mites in Colonies Producing Honey or Royal Jelly
}

by

Priscila Wielewski ${ }^{1}$, Vagner de Alencar Arnaut de Toledo ${ }^{2 *}$, Elias Nunes Martins ${ }^{2}$, Fabiana Martins Costa-Maia ${ }^{1}$, Patrícia Faquinello ${ }^{3}$, Daniela Andressa Lino-Lourenço ${ }^{2}$,

Maria Claudia Colla Ruvolo-Takasusuki ${ }^{2} \&$ Carlos Antonio Lopes de Oliveira ${ }^{2}$ \& Maria Josiane Sereia ${ }^{4}$

\section{ABSTRACT}

Genetic and phenotypic parameters for hygienic behavior, invasion and infestation rates, total and effective reproduction of Varroa destructor in Africanized honeybee colonies producing honey (20 hives) or royal jelly (30 mini-hives) were analyzed. The significance of monthly fixed effects, type of product (honey and royal jelly) and their interactions were verified through generalized linear model procedures. Software WinBugs (Bayesian Inference Using Gibbs Sampling) with Bayesian inference was employed for (co)variance estimates. The average values for colonies producing honey or royal jelly were 74.38 and $71.40 \%$ for hygienic behavior in 24 hours; infestation rates 8.30 and $11.40 \%$; invasion rates 9.50 and $7.50 \%$; total reproduction 1.02 and $0.55 \%$; effective reproduction was 0.62 and $0.33 \%$, respectively. The additive genetic variance for invasion (0.16), total reproduction $(0.25)$ and effective reproduction (0.94) rates of the mite were higher than estimates for hygienic behavior in 24 hours $(0.05)$ and infestation rate (0.04). Mean heritability for hygienic behavior, infestation and invasion rates, total and effective reproduction of the mite were

\footnotetext{
${ }^{1}$ Universidade Tecnológica Federal do Paraná, Campus Dois Vizinhos Estrada para Boa Esperança, km 04 CEP 85660-000, Dois Vizinhos - Pr, Brasil ${ }^{2}$

${ }^{2}$ Universidade Estadual de Maringá - Avenida Colombo, 5790, CEP 87020-900 Maringá - Paraná, Brasil

${ }^{3}$ Universidade Federal do Recôncavo da Bahia - Rua Rui Barbosa, 710, CEP: 44380-000, Cruz das Almas -Bahia, Brasil.

${ }^{4}$ Universidade Tecnológica Federal do Paraná, Campus Campo Mourão BR 369 - km 0,5 CEP 87301 006 - Caixa Postal: 271 - Campo Mourão-Pr, Brasil

*author for correspondence - abelha.vagner@gmail.com
} 
$0.58,0.54,0.56,0.63$ and 0.61 , respectively. The genetic correlation of -0.48 for hygienic behavior with total reproduction rate of Varroa destructor shows that hygienic behavior may be the most interesting trait for selection. Besides a heritability of high magnitude, when combined with the total reproduction rate of the mite, it has a high and antagonistic correlation. Consequently, in cases of high infestation of Varroa destructor, the selection for hygienic behavior would decrease the reproduction rate of the mite.

Key-words: beebreeding, heritability, genetic correlation, phenotypic correlation, Bayesian inference

\section{RESUMO}

Foram analisados os parâmetros genéticos e fenotípicos para o comportamento higiênico e as taxas de invasão, infestação e reprodução total e efetiva do ácaro Varroa destructor em colônias de abelhas Apis mellifera africanizadas produtoras de mel (20) ou geleia real (30). Foi verificada a significância dos efeitos fixos de mês, tipo de produto e suas interações, utilizando o procedimento de modelos lineares generalizados. Para a estimação das (co)variâncias foi utilizado o software WinBUGS por meio de inferência Bayesiana. As médias para colônias produtoras de mel ou geleia real, respectivamente, foram: para o comportamento higiênico em 24h, 74,38 e 71,40\%; taxas de infestação 8,30 e 11,40\%; taxas de invasão 9,50 e 7,5\%; taxas de reprodução total 1,02 e 0,55 e reprodução efetiva 0,62 e 0,33 . As herdabilidades médias para comportamento higiênico, taxa de infestação, taxa de invasão, taxa de reprodução total e efetiva do ácaro foram 0,58, 0,54, 0,56, 0,63 e 0,61, respectivamente. A correlação genética encontrada de $-0,48$ para a característica comportamento higiênico com taxa de reprodução total do ácaro Varroa destructor indicou que o comportamento higiênico pode ser considerado a característica mais interessante para seleção, pois além de apresentar herdabilidade de alta magnitude, quando associada à taxa de reprodução total do ácaro apresenta uma correlação alta e 
antagônica, sendo assim, em casos de alta infestação do ácaro Varroa destructor, selecionando-se para comportamento higiênico estaríamos diminuindo a taxa de reprodução do ácaro.

Palavras-chave: melhoramento de abelhas, herdabilidade, correlação genética, correlação fenotípica, inferência bayesiana

\section{INTRODUCTION}

Africanized honeybees are specifically significant owing to their positive adaptation in Brazil and to their honey production. Since the honey bee has high genetic variability between queens from the same geographical region (Winston et al. 1983) with regard to economical features, the honeybees are interesting examples within a genetic improvement program.

The peculiarity of honeybees makes genetic improvement difficult due to environmental influences and genetic differences in matinglevel (Bienefeld et al. 2007). However, researchers in many countries are undertaking genetic improvement with some success. The best honeybee production selection programs in the USA necessarily include the selection of hygienic honeybees.

Hygienic behavior is an efficient resistance mechanism against brood diseases and has been well-documented since the 1940s when much research was undertaken in the area (Message 2006). This hygienic behavior includes the colony capacity to inhibit infestation by mites of the genus Varroa.

The mite Varroa destructor, which causes varroatosis in Apiscerana and Apis mellifera, was introduced in Brazilian apiculture at the beginning of the 1970s. Called Varroa jacobsoni, the genus was introduced in Brazil through Paraguayan beekeepers (Morse \& Gonçalves 1979). In turn, the queens bought from Paraguay had been imported from Japan.

Population dynamics of the mite Varroa have varied by region (Calderón et al. 2010). In Brazil were greatly different from those reported in other varroatosis infested regions. Over 20\% rates, initially reported, 
brought concern to researchers and beekeepers (Moretto et al. 1991). However, as the mite spread itself throughout Brazilian regions, it became clear that infestation rates, although initially high, declined some years after the first infestation.

A balance seems to have been reached between the mite Varroa destructor and Africanized honeybees in climate conditions of Brazil (Moretto \& Mello 2001). In some regions of the country the varroatosis infestation rates reached the very low percentage of $2 \%$ (Moretto et al. 1993, Carneiro et al. 2007, Calderón et al. 2010).

This research was carried out to estimate phenotypic and genetic parameters which report hygienic behavior with the population dynamics of Varroa destructor in Africanized honeybee colonies which produce royal jelly or honey. The possible inclusion of these traits in genetic improvement programs in Brazil may be achieved.

\section{MATERIAL AND METHODS}

The assay was undertaken at the Central Apiary of the Iguatemi Experimental Farm of Universidade Estadual de Maringá, Maringá PR Brazil, from February 2009 to November 2009. Fifty colonies of Africanized honeybees, 30 in mini-hives which produced royal jelly, and 20 in Langstroth hives with supers, which produced honey which was used.

\section{Production of queens}

Queen production for the production of their daughters from honeyproducing colonies to replace the queens of royal jelly-producing colonies was undertaken in October 2008, April 2009 and August 2009. Modified Doolittle (1889) method for queen production, or rather, the grafting of worker larvae from their original cell to acrylic cups with royal jelly diluted in distilled water $(1: 1)$, was employed.

Whereas ten queens were randomly replaced in January 2009 in the 30 royal jelly-producing colonies, nine queens were once more randomly replaced in April and 12 in August. 


\section{Production of royal jelly}

A modified Doolittle (1889) method was employed for royal jelly production whilst its grafting and collection were undertaken twice a week. So that appropriate larvae for royal jelly production could be obtained, grafting was previously programmed with the introduction of an empty comb four days prior to grafting and placed in the center of the different colonies in the ten-frame nests or five-frame nuclei in Langstroth hive model. After larvae grafting, the cup bars were carefully placed in their respective Langstroth hive or mini-hive.

\section{Hygienic behavior}

Rothenbühler (1964) and Newton et al. (1975), revised by Spivak \& Downey (1998) reported that the hygienic behavior test establishes the time spent by honeybee colonies to detect, uncap and remove dead brood worker honeybees by freezing $\left(-20^{\circ} \mathrm{C}\right.$ during $\left.24 \mathrm{~h}\right)$ from one section of the $5 \times 6 \mathrm{~cm}$ comb (with approximately 100 capped brood pupae of the comb), separated from the colony nest for evaluation, and to determine whether the colony is or not hygienic.

Royal jelly- and honey-producing colonies underwent hygienic behavior test (Taber 1982, Gramacho 1995). A comb with capped brood worker bees, aged 17-18 days, or rather, during the rose-colored pupa phase, placed on both sides, $\mathrm{A}$ and $\mathrm{B}$, was removed from each colony. The central section with $5 \times 10 \mathrm{~cm}$ had been removed from the comb, was photographed, and frozen at $-20^{\circ} \mathrm{C}$ for $24 \mathrm{~h}$. After that, the comb section was then conditioned in an incubator at $34^{\circ} \mathrm{C}$ and $60 \%$ humidity during $4 \mathrm{~h}$ to dry and establish the same internal temperature of the colonies. After restored to their respective colonies, the sections were again photographed $24 \mathrm{~h}$ for counting of the uncapped cells.

Hygienic behavior percentages were obtained by calculating the number of alveoli of capped brood at zero hour as a function of the number of alveoli of the remaining capped brood in $24 \mathrm{~h}$.

Further, 15, 11, 12, 14, 11 and 7 out of the 20 honey-producing matrix colonies were evaluated for hygienic behavior respectively in February, 
March, April, May, June and July 2009. Similarly, 14, 18, 11 and 13 out of 30 royal jelly-producing colonies were evaluated respectively in February, March, April and September 2009.

Estimates for hygienic behavior were obtained by calculating:

$$
\left.\mathrm{CH}_{\mathrm{x}}=\left(\mathrm{TO}_{\text {zero hour }}-\mathrm{AO}_{\mathrm{x}}\right) / \mathrm{TO}_{\text {zero hour }}\right)
$$

Where,

$\mathrm{CH}_{x}$ is the relationship between the number of cleaned alveoli and the total number of capped brood cells in which ${ }_{x}$ reaches $24 \mathrm{~h}$;

$T O_{\text {zero bour }}$ is the total number of capped brood cells at zero hour; $24 \mathrm{~h}$.

$A O_{x}$ is the total number of capped brood cells in which ${ }_{x}$ reaches

The number of cells with partially removed pupae (crp), pointed (cp) and uncapped (cd) which, as a rule, demonstrate the hygienic behavior corresponding to uncapping activities (pointing and destruction of the opercula or uncapping).

Variables analyzed with regard to Varroa destructor consisted of:

\section{Infestation rate of adult worker honeybees}

The mite infestation rate, as proposed by Stort et al. (1981), was undertaken to verify the number of mites in worker honeybees. The method retrieves approximately one hundred adult worker honeybees from a comb at the centre and placed in a dish with alcohol $70 \%$ and the contents stirred. Total number of worker honeybees and mites was counted to evaluate each colony infestation percentage.

\section{Invasion rate in worker pupae}

Observation of the number of Varroa mites, as proposed by De Jong \& Gonçalves (1981), was performed to estimate the number of mites in the worker pupae. The method included the retrieval of a comb of capped brood from each colony. Opercula were removed with insect pin from 100 ( 50 from each side of the comb) pupae. Female mites and their offspring in pupae and alveoli were analyzed by attached light.

Tests were undertaken in the twenty honey-producing colonies: five colonies were tested during February 2009; six in March; 11 in April; eight in May; 15 in June and 10 in July 2009. 
In the 30 royal jelly-producing colonies the test was undertaken in 11 colonies during February 2009; seven in March; nine in April and nine in September.

\section{Reproduction rates of the mite Varroa destructor}

Mite total reproduction rate was calculated as follows:

TRT $=$ total number of descendents / (number of adult females)

Mite effective reproduction rate was calculated as follows:

TRE $=$ number of deutonymphs + young adults / (number of female adults)

Whereas total reproduction rate (TRT) is the total number of descendents produced by the mite, effective reproduction rate is the number of viable descendants. Since worker pupae under analysis were approximately 18 - 19 days old, there was no sufficient time for the final development of the mite immature forms, in Africanized honeybees. Therefore, only deutonymphs, female adults and young females could parasitize the forthcoming worker honeybee one to two days after analysis. This fact actually contributed towards the mite reproduction.

When Toledo \& Nogueira-Couto (1996) investigated Africanized honeybees and hybrids from Caucasian, Italian and Carniolian sister queens, they found no statistical difference for Varroa total and effective reproduction rates.

\section{Data analysis}

R Development Core Team statistic program (2009) gave a previous analysis of data to verify the significance of fixed month effects, type of product (royal jelly or honey) and their interactions. Since Shapiro-Wilk test showed non-normality of data, Generalized Linear Models (GLM) procedures were used, in which it was assumed the Gama distribution and inverse link function, for variables. Data were corrected when any significant effect occurred.

Since worker honeybees that performed the hygienic behavior are middle-aged, averaging 15.2 daysold (Arathiet al. 2000), worker groups 


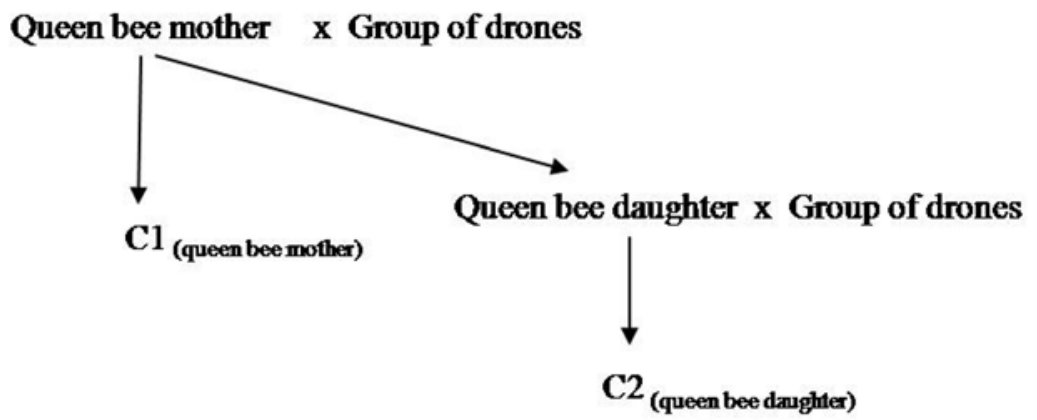

Fig.1. Relationship among honey-producing $(\mathrm{C} 1)$ and royal jelly producing colonies (C2).

executing the same task in the colony are changed approximately at every 35.2 days.

Fig. 1 shows the relationship among colonies of queen bee mothers and those of the queen bee daughters amounted to 0.25 since fatherhood is unknown.

Corrected covariance among colonies of queen bee mothers and those of queen bee daughters amounts to 0.25 of additive genetic variance.

The two colonies may be described as featuring aunt-niece relationships, or rather; the queen bee from which $\mathrm{C} 1$ derived is the queen mother that produced C2.

Analysis strategy took the traits in pairs while considering that the same characteristic in the queen bee mother colonies was another characteristic when evaluated in the queen bee daughter colony.

Data were organized through the pairing of recording of the queen bee mother colonies and those of the queen bee daughter colonies. The archive in each analysis with two traits was formed by four columns: the first refers to recording of trait 1 in the queen bee mother colonies; the second refers to recording of trait 2 in queen bee mother colonies; the third refers to recording of trait 1 in the queen bee daughter colonies; the fourth refers to recording of trait 2 in the queen bee daughter colonies. Employing the following multivariated structure, we have: 


$$
Y_{i j k} \sim N M V\left(\mu_{k} ; \Sigma_{k}\right) \text {, or rather, }
$$

$$
\left[\begin{array}{l}
y_{1} \\
y_{2} \\
y_{3} \\
y_{4}
\end{array}\right] \quad N M V\left\{\left[\begin{array}{l}
0 \\
0 \\
0 \\
0
\end{array}\right] ;\left[\begin{array}{cccc}
\sigma_{y_{1}}^{2} & \sigma_{y_{1} y_{2}} & \sigma_{y_{1} y_{3}} & \sigma_{y_{1} y_{4}} \\
\sigma_{y_{2} y_{1}} & \sigma_{y_{2}}^{2} & \sigma_{y_{2} y_{3}} & \sigma_{y_{2} y_{4}} \\
\sigma_{y_{3} y_{1}} & \sigma_{y_{3} y_{2}} & \sigma_{y_{3}}^{2} & \sigma_{y_{3} y_{4}} \\
\sigma_{y_{4} y_{1}} & \sigma_{y_{4} y_{2}} & \sigma_{y_{4} y_{3}} & \sigma_{y_{4}}^{2}
\end{array}\right]\right.
$$

In the case of matrix $\Sigma_{k}$, the variance matrix and (co)variance in the reports, inverted Wishart distribution, was taken up by $\Sigma_{k} \sim \mathrm{IW}\left(\mathrm{R}_{\mathrm{k}} \mathrm{J}\right)$ with $\mathrm{R}_{\mathrm{k}}=\mathrm{I}_{\mathrm{J}}=\mathrm{I}_{4}$ in which $\mathrm{I}$ is the identity matrix and the scale parameter is equal to four.

Marginal distribution for parameters was obtained a posteriori by software WinBUGS 1.4.2 (Spiegelhalter et al. 1994) which precedes Bayesian analysis. One million rates were generated for each parameter in a Monte Carlo Markov Chain (MCMC) process, declining initial discardingperiod and with all sampled rates inserted within a final chain. Chain convergence was tested by criteria proposed by Heidelberger $\&$ Welch (1983) and Geweke (1992), implemented in a CODA library, available in the computer system R Development Core Team (2009).

Based on estimated rates for $\Sigma_{k}$ and employing a program developed by computer system R Development Core Team (2009), phenotypic $\left(\sigma_{y \mathrm{C} 1}^{2}\right.$ and $\left.\sigma_{y \mathrm{C} 2}^{2}\right)$ and additive genetic $\left(\sigma_{a \mathrm{C} 1}^{2}\right.$ and $\left.\sigma_{a \mathrm{C} 2}^{2}\right)$ variance for the two traits and phenotypic $\left(\sigma_{y \mathrm{C} 1 y \mathrm{C} 2}^{2}\right)$ and additive genetic $\left(\sigma^{2}{ }_{a \mathrm{ClaC} 2}\right)$ covariance between the two was calculated as follows:

$$
\begin{gathered}
\sigma_{y \mathrm{C} 1}^{2}=\frac{\sigma_{y_{1}}^{2}+\sigma_{y_{3}}^{2}}{2} \\
\sigma_{y \mathrm{C} 2}^{2}=\frac{\sigma_{y_{2}}^{2}+\sigma_{y_{4}}^{2}}{2}
\end{gathered}
$$




$$
\begin{gathered}
\sigma_{y \mathrm{C} 1 y \mathrm{C} 2}^{2}=\frac{\sigma_{y_{1} y_{4}}+\sigma_{y_{2} y_{3}}}{2} \\
\sigma_{a \mathrm{C} 1}^{2}=4 \sigma_{y_{1} y_{3}} \\
\sigma_{a \mathrm{C} 2}^{2}=4 \sigma_{y_{2} y_{4}} \\
\sigma_{a \mathrm{C} 1 a \mathrm{C} 2}^{2}=4 \sigma y \mathrm{C} 1 y \mathrm{C} 2
\end{gathered}
$$

So that heritability and correlation would be within the parameter space established for them, namely, from 0 to 1 and from -1 to 1 , respectively, samples that failed to satisfy the above mentioned conditions were discarded from the Markov chain. The new chain underwent convergence tests proposed by Heidelberger \& Welch (1983) and Geweke (1992).

Mean distribution rate, median, standard error, credibility interval and high density region were set at $95 \%$ for each variance component and genetic parameter.

\section{RESULTS AND DISCUSSION}

Percentage mean for hygienic behavior in $24 \mathrm{~h}$ ( $\mathrm{CH} 24)$, adult infestation rate, invasion rate in the pupae, total and effective reproduction rate for honey and royal jelly-producing colonies were respectively 74.38 and $71.40 \%$; 8.30 and $11.40 \%$; 9.50 and $7.5 \% ; 102.40$ and $54.60 \%$; 62.00 and $33.00 \%$.

Previous data analysis did not show effects of production types for hygienic behavior in $24 \mathrm{~h}(\mathrm{CH} 24)$.

Interaction existed for product and period in the case of mite infestation in adult honeybees. This fact shows that during the cold months there was an increase in infestation rates for honey-producing colonies. The number of colony individuals during this period decreased and an increase in mite concentrations occurred (Nogueira-Couto 1991). 
Product type, honey and royal jelly, was significant for the pupa invasion rate, respectively with means of 9.5 and $7.5 \%$. According to Segndo Lee et al. (2010) the mite prefers the nurse bees, which tend to stay in the brood frame. Thus, the colonies submitted to royal jelly production, which need a greater amount of nurse bees responsible for feeding the queen larvae, are probably more affected by Varroa mites.

Moretto et al. (1991) verified invasion rates in pupae in three regions and concluded that Africanized honeybees were more resistant to Varroa than Italian honeybees bred with Africanized honeybees. In Brazil, Africanized honeybees tolerate the mite, and high swarming rates contribute to this tolerance (Boecking \& Ritter 1993).

Total and effective reproduction rates of Varroa mites were not affected by period or product type.

Table 1 shows estimates of addictive genetic and phenotypic covariance in a two-trait analysis for variables under analysis. Additive genetic variance for invasion (0.16), total (0.25) and effective (0.94) reproduction rates of the mite are higher than those estimated for hygienic behavior in $24 \mathrm{~h}(0.05)$ and infestation (0.04). Estimates for phenotypic variance had a similar behavior. Higher additive genetic variance proportion for the mite reproduction rates may be due to higher precision of tye method employed when compared to infestation, invasion and hygienic behavior.

Table 2 shows estimates of heritability and the respective credibility intervals and high density regions in a two-trait analysis.

Mean heritability for hygienic behavior, infestation rate, invasion rate, total and effective reproduction rate of mites were respectively $0.58,0.54$, 0.56, 0.63 and 0.61. Although Spivak \& Gilliam (1993) said that this behavior is genetically determined, but not always expressed, it seems to be dependent on environmental factors of the colony. Harbo \& Harris (1999) recorded heritability estimates of 0.65 for such behavior in $24 \mathrm{~h}$. In the following year, Boecking et al. (2000) estimated heritability at 0.36 for the removal of capped brood perforated between 13 and $15 \mathrm{~h}$. 
Table 1. Estimates of components of addictive genetic and phenotypic covariance with respective intervals of credibility and high density regions, at $95 \%$, in a two-trait analysis for hygienic behavior in $24 \mathrm{~h}$ infestation, invation and total and effective reproductive rates of Varroa destructor in Africanized honeybees.

\begin{tabular}{|c|c|c|c|}
\hline Components & Estimates & Credibility interval & High density region \\
\hline$\sigma_{a 1}^{2}$ & 0.05 & $0.005-0.12$ & $0.0004-0.10$ \\
\hline$\sigma_{\mathrm{a12}}$ & -0.001 & $-0.06-0.05$ & $-0.06-0.05$ \\
\hline$\sigma_{\mathrm{ala3}}$ & -0.001 & $-0.10-0.10$ & $-0.10-0.10$ \\
\hline$\sigma_{\text {ala4 }}$ & -0.21 & $-0.65-0.21$ & $-0.63-0.23$ \\
\hline$\sigma_{\text {alas }}$ & 0.004 & $-0.35-0.35$ & $-0.35-0.35$ \\
\hline$\sigma^{2}$ & 0.04 & $0.004-0.10$ & $0.0005-0.10$ \\
\hline$\sigma_{\mathrm{a} 2 a 3}$ & 0.001 & $-0.04-0.04$ & $-0.04-0.04$ \\
\hline$\sigma_{\text {a2a4 }}$ & -0.07 & $-0.47-0.28$ & $-0.45-0.30$ \\
\hline$\sigma_{a 25}$ & 0.07 & $-0.29-0.41$ & $-0.29-0.41$ \\
\hline$\sigma^{2}$ & 0.16 & $0.02-0.38$ & $0.002-0.33$ \\
\hline$\sigma_{\mathrm{a} 3 \mathrm{a} 4}$ & 0.07 & $-0.08-0.23$ & $-0.08-0.23$ \\
\hline$\sigma_{\text {a3as }}$ & 0.01 & $-0.10-0.12$ & $-0.10-0.12$ \\
\hline$\sigma_{a 4}^{233}$ & 0.25 & $0.05-0.52$ & $0.02-0.47$ \\
\hline$\sigma$ & 0.26 & $-0.36-0.82$ & $-0.32-0.85$ \\
\hline$\sigma^{22^{23 a}}$ & 0.94 & $0.18-2.31$ & $0.06-1.98$ \\
\hline$\sigma_{y 1}^{2^{33}}$ & 0.09 & $0.05-0.15$ & $0.05-0.15$ \\
\hline$\sigma_{\mathrm{yly2}}$ & -0.0003 & $-0.01-0.01$ & $-0.01-0.01$ \\
\hline$\sigma_{y l y 3}$ & -0.0002 & $-0.02-0.02$ & $-0.02-0.02$ \\
\hline$\sigma_{\text {yly } 4}$ & -0.05 & $-0.16-0.05$ & $-0.16-0.05$ \\
\hline$\sigma_{\mathrm{vly5}}$ & 0.001 & $-0.08-0.08$ & $-0.08-0.08$ \\
\hline$\sigma_{y 2}^{2}$ & 0.08 & $0.05-0.13$ & $0.05-0.12$ \\
\hline$\sigma_{y 2 y 3}$ & 0.0002 & $-0.01-0.01$ & $-0.01-0.01$ \\
\hline$\sigma_{y 2 y 4}$ & -0.02 & $-0.12-0.07$ & $-0.11-0.08$ \\
\hline$\sigma_{\mathrm{y} 2 y 5}$ & 0.02 & $-0.07-0.10$ & $-0.07-0.10$ \\
\hline$\sigma_{y 3}^{2}$ & 0.29 & $0.16-0.52$ & $0.14-0.47$ \\
\hline$\sigma_{y 3 y 4}$ & 0.02 & $-0.02-0.05$ & $-0.02-0.05$ \\
\hline$\sigma_{y 3 y 5}$ & 0.002 & $-0.02-0.02$ & $-0.02-0.02$ \\
\hline$\sigma_{y 4}^{2}$ & 0.37 & $0.21-0.66$ & $0.18-0.59$ \\
\hline$\sigma_{\mathrm{v4y} 5}$ & 0.07 & $-0.09-0.20$ & $-0.08-0.21$ \\
\hline$\sigma_{y 5}^{2}$ & 1.37 & $0.65-3.01$ & $0.54-2.59$ \\
\hline
\end{tabular}

${ }^{*} \mathrm{a}$ and $y$ represent the addictive genetic and phenotypic effects, respectively, for all components; indexes 1,2, 3,4 and 5 correspond to the hygienic behavior in $24 \mathrm{~h}$, infestation, invasion, total and effective reproduction rate of the mite, respectively. 
Wielewski, P. et al. - Hygenic Behavior and Varroa destructor in Honeybee Colonies

Table 2. Estimates of heritability $\left(b^{2}\right)$ in a two-trait analysis and respective credibility intervals and high density regions at $95 \%$, and mean heritability for hygienic behavior in $24 \mathrm{~h}$, infestation, invasion and reproduction rates of mite Varroa destructor in Africanized honeybees.

\begin{tabular}{|c|c|c|c|c|}
\hline Characteristic & Two-trait analysis & Estimates & Credibility interval & High density region \\
\hline \multirow{4}{*}{1} & $\mathrm{~h}^{2}{ }_{\mathrm{ala2} 2}$ & 0.52 & $0.06-0.97$ & $0.09-0.99$ \\
\hline & $h^{2}{ }_{a 1 a 3}$ & 0.57 & $0.07-0.98$ & $0.12-0.99$ \\
\hline & $\mathrm{h}^{2}{ }_{\mathrm{ala} a}$ & 0.56 & $0.07-0.98$ & $0.12-0.99$ \\
\hline & $h^{2}{ }_{a 1 a 5}$ & 0.66 & $0.12-0.99$ & $0.19-0.99$ \\
\hline \multirow[t]{2}{*}{ Mean } & $\mathrm{H}^{2}$ & 0.58 & - & - \\
\hline & $h^{2}{ }^{2} 2 a 1$ & 0.55 & $0.07-0.98$ & $0.11-0.99$ \\
\hline \multirow[t]{3}{*}{2} & $h^{2}{ }_{2223}$ & 0.52 & $0.06-0.97$ & $0.09-0.99$ \\
\hline & $h^{2}{ }_{22 a 4}$ & 0.47 & $0.05-0.96$ & $0.03-0.93$ \\
\hline & $h^{2}{ }_{2225}$ & 0.64 & $0.13-0.98$ & $0.19-0.99$ \\
\hline \multirow[t]{2}{*}{ Mean } & $H^{2}$ & 0.54 & - & - \\
\hline & $\mathrm{h}^{2}$ & 0.56 & $0.07-0.98$ & $0.11-0.99$ \\
\hline \multirow[t]{3}{*}{3} & $h^{2}{ }^{2}$ & 0.55 & $0.07-0.98$ & $0.11-0.99$ \\
\hline & $h^{2}{ }_{33 a 4}$ & 0.56 & $0.07-0.98$ & $0.11-0.99$ \\
\hline & $h^{2}{ }^{2} 325$ & 0.57 & $0.07-0.98$ & $0.12-0.99$ \\
\hline \multirow[t]{2}{*}{ Mean } & $H^{2}$ & 0.56 & - & - \\
\hline & $\mathrm{h}^{2}{ }^{2}{ }_{4 a 1}$ & 0.67 & $0.17-0.99$ & $0.23-0.99$ \\
\hline \multirow[t]{3}{*}{4} & $\mathrm{~h}^{2}{ }_{\mathrm{a} 4 \mathrm{2} 2}$ & 0.59 & $0.09-0.98$ & $0.15-0.99$ \\
\hline & $\mathrm{h}^{2}{ }^{2} 4 \mathrm{a3}$ & 0.58 & $0.08-0.98$ & $0.13-0.99$ \\
\hline & $\mathrm{h}^{2}{ }^{24 a 55}$ & 0.68 & $0.16-0.99$ & $0.23-0.99$ \\
\hline \multirow[t]{2}{*}{ Mean } & $H^{2}$ & 0.63 & - & - \\
\hline & $\begin{array}{l}11 \\
\mathrm{~h}^{2}{ }^{2} \mathrm{al}_{\mathrm{a}}\end{array}$ & 0.68 & $0.16-0.99$ & $0.24-0.99$ \\
\hline \multirow[t]{3}{*}{5} & $h^{2}{ }_{55 a 2}$ & 0.56 & $0.07-0.98$ & $0.12-0.99$ \\
\hline & $h^{2}{ }_{a 5 a 3}$ & 0.54 & $0.06-0.98$ & $0.11-0.99$ \\
\hline & $\mathrm{h}^{2}{ }_{\mathrm{a} 5 \mathrm{a} 4 \mathrm{aj}}$ & 0.66 & $0.15-0.99$ & $0.21-0.99$ \\
\hline Mean & $H^{2}$ & 0.61 & - & - \\
\hline
\end{tabular}

Costa-Maia (2009) estimated heritability of 0.28 for this component by Bayesian inference.

Credibility intervals for heritability estimates were not only broad and positive but also coincided with high density regions.

Falconer (1987) reported on the importance of heritability due to the fact that it helps in the estimate of addictive genetic variance associated to a trait within a specific population.

Table 3 shows estimates of genetic and phenotypic correlation among the traits under analysis. The positive correlations are: adult infestation 
Table 3. Estimates of genetic $\left(r_{g}\right)$ and phenotypic $\left(r_{\gamma}\right)$ correlation coupled to their respective credibility intervals and high density regions at $95 \%$, within a two-trait analysis, for hygienic behavior in $24 \mathrm{~h}$, infestation, invasion and total and effective reproduction rates of the mite Varroa destructor in Africanized honeybees

\begin{tabular}{|c|c|c|c|}
\hline Components & Estimates & Credibility interval & High density region \\
\hline$r_{g 1,2}$ & -0.02 & $-0.95-0.94$ & $-0.99-0.88$ \\
\hline $\mathrm{rg}_{1,3}$ & -0.007 & $-0.95-0.94$ & $-0.99-0.89$ \\
\hline & -0.48 & $-0.99-0.69$ & $-0.99-0.50$ \\
\hline $\begin{array}{l}g_{1,4} \\
\operatorname{rg}_{1,5}\end{array}$ & 0.01 & $-0.93-0.94$ & $-0.88-0.99$ \\
\hline $\mathrm{rg}_{2,3}$ & 0.02 & $-0.93-0.94$ & $-0.88-0.99$ \\
\hline $\mathrm{rg}_{2,4}$ & -0.19 & $-0.96-0.89$ & $-0.99-0.80$ \\
\hline $\mathrm{rg}_{2,5}$ & 0.21 & $-0.87-0.97$ & $-0.75-0.99$ \\
\hline $\mathrm{rg}_{3,4}$ & 0.46 & $-0.73-0.99$ & $-0.52-0.99$ \\
\hline $\mathrm{rg}_{3,5}$ & 0.06 & $-0.93-0.95$ & $-0.87-0.99$ \\
\hline $\mathrm{rg}_{4,5}$ & 0.43 & $-0.65-0.98$ & $-0.44-0.99$ \\
\hline $\mathrm{ry}_{1,2}$ & -0.003 & $-0.15-0.14$ & $-0.15-0.15$ \\
\hline $\mathrm{ry}_{1,3}$ & -0.001 & $-0.16-0.15$ & $-0.16-0.16$ \\
\hline $\mathrm{ry}_{1,4}$ & -0.08 & $-0.19-0.07$ & $-0.21-0.07$ \\
\hline $\mathrm{ry}_{1,5}$ & 0.002 & $-0.17-0.17$ & $-0.17-0.17$ \\
\hline$r y_{2,3}$ & 0.003 & $-0.14-0.15$ & $-0.14-0.15$ \\
\hline$r y_{2,4}$ & -0.03 & $-0.16-0.11$ & $-0.17-0.11$ \\
\hline & 0.03 & $-0.13-0.18$ & $-0.12-0.18$ \\
\hline & 0.07 & $-0.07-0.19$ & $-0.06-0.20$ \\
\hline $\mathrm{ry}_{3,5}$ & 0.01 & $-0.14-0.16$ & $-0.14-0.16$ \\
\hline$r y_{4,5}$ & 0.07 & $-0.09-0.19$ & $-0.08-0.20$ \\
\hline
\end{tabular}

rates and the effective reproduction rate (0.21); invasion rate in pupae and the total reproduction rate $(0.46)$; total reproduction rate and effective reproduction rate $(0.43)$. The other correlations are only slightly genetically and phenotypically related owing to their low rates.

The most important negative genetic correlation is hygienic behavior and the mite total reproduction rate $(-0.48)$. The above antagonism, namely, the selection of Africanized honeybees for hygienic behavior, decreases Varroa destructor mite total reproduction rate. 
Since credibility intervals for all broad estimates included a zero value in their intervals, no correlation lies among the analyzed traits. However, when data symmetry is investigated, their probability in fact exists with higher and lower rates than zero value. Figs. 2 to 11 (see appendix) show estimates of phenotypic and genetic correlation to demonstrate probabilities and whether one trait affects or not another trait.

Figs. 2 (hygienic behavior with infestation), 3 (hygienic behavior with invasion), 4 (hygienic behavior with effective reproduction rate), 5 (infestation with invasion) and 6 (invasion with effective reproduction rate) show that phenotypic and genetic correlation have graphic symmetries and highest frequencies close to zero. This fact shows that correlation is very low and thus traits are genetically only slightly related.

Nocorrelation exists between hygienic behavior and Varroa infestation rates, since these traits are not interdependent (Fig. 2). When colonies with hygienic behavior are selected, there may not be any impact on the mite invasion rates (Fig. 3). This fact is shown in Table 3 by correlation -0.007 with a credibility interval ranging between -0.95 and 0.94 .

Fig. 5 shows that infestation rate is not correlated with the Varroa invasion rate. This may be explained by worker grooming, which may prevent the mites from invading the cells of the capped brood. Grooming may have an important role in the maintenance of low infestation rates (Junkes et al. 2007).

Figs. 7 (hygienic behavior with total reproduction rate), 8 (infestation with total reproduction rate), 9 (infestation with total reproduction rate), 10 (invasion with total reproduction rate) and 11 (total reproduction rate with the mite effective reproduction rate) show that phenotypic and genetic correlation with a high probability. In fact, these are asymmetrical figures displaced from zero rates. Figs. 4 and 7 show the highest frequencies of less than zero rates and represent great probability that genetic correlations exist and are negative.

Hygienic behavior may be antagonistic to total reproduction rate of the mites (Fig. 7). This fact may be explained by the characteristics' 
independence. In fact, the mite may reproduce itself regardless of the colonies' efficient hygienic behavior. Conversely, the mite may be in the colonies without reproducing itself (Fig. 8).

However, if the infestation rate increases, the mite effective reproduction rate may increase too (Fig. 9). This fact may occur since mite reproduction rates may increase owing to age with a possible introduction of a new recently occurring haplotype of the mite in Brazil. The reproductive capacity of the mite may be thus increasing (Carneiro et al. 2007). Increasing the invasion rate might also increase the total reproduction rate of the mite (Fig. 10).

Fig. 11 shows that there may be a correlation among reproduction rates of the mite when above zero rates occur. This is due to the fact that rates are mutually dependent.

Since criteria for selection should be chosen so that selected honeybees do not lose their adaptive characteristics, such as their relative resistance to diseases (Toledo \& Mouro 2005), a higher negative correlation for hygienic behavior with total reproduction rate, as that found in the current research, should be taken into account and analyzed with great care. Actually, hygienic behavior associated with all the other traits had low correlation and all traits associated with total reproduction rates had significant correlation. This may occur because hygienic behavior simulates problematic brood and total reproduction rate might be a highly precise measurement since the pupae analyzed for this rate (brown eyed pupae) indicate the precise phase of the mite reproduction.

It should be also emphasized that the infestation rate of the mite Varroa destructor in Brazil is relatively low. The rate interferes with the mite reproduction rate since when no infestation occurs, no reproduction rate exists.

However, at low infestation rates the hygienic behavior trait is still the most recommended selection criterion. Selections for the above trait would solve the reproduction problem of the mite Varroa destructor in the context of brood diseases. 
When high infestation rates of the mite exist, the most important criterion is hygienic behavior. In fact, it presents high level heritability and negative correlation with total reproduction rate of the mite Varroa destructor.

\section{ACKNOWLEDGMENTS}

The authors would like to thank the National Research Council (CNPq, process no.301943/2005-2 and Araucaria Foundation 37/2005 4025 for financial support.

\section{REFERENCES}

Arathi, H.S., I. Burns \& M. Spivak 2000. Ethology of hygienic behaviour in honey bee Apis mellifera L. (Hymenoptera: Apidae): behavioural repertoire of hygienic bees. Ethology 106:365-379.

Bienefeld, K., K. Ehrhardt \& F. Reinhardt 2007. Genetic evaluation in the honey bee considering queen and worker effects - A BLUP- Animal Model approach. Apidologie 38:77-85.

Boecking, O.\&W. Ritter 1993. Grooming and removal behaviour of Apis mellifera in Tunisia against Varroa jacobsoni. Journal of Apicultural Research 32:127-134.

Boecking, O., K. Bienefeld \& W. Drescher 2000. Heritability of the varroa-specific hygienic behavior in honeybees (Hymenoptera: Apidae). Journal Animal Breeding and Genetics 117:417-424.

Calderón, R.A.,J.W.Van Veen, M.J. Sommeijer \& L.A. Sanchez 2010. Reproductive biology of Varroa destructor in Africanized honeybees (Apismellifera). Experimental and Applied Acarology 50:281-297.

Carneiro, F.E., R.R. Torres, R. Strapazzon, S.A. Ramírez, J.C. Jr. Guerra, D.F. Koling \& G. Moretto 2007. Changes in the reproductive ability of the mite Varroa destructor (Anderson \& Trueman) in Africanized honey bees (Apis mellifera L.) colonies in southern Brazil. Neotropical Entomology 36:949-952.

Costa-Maia, F.M. Aspectos genéticos da produção de mel e comportamento higiênico em abelhas Apis mellifera africanizadas. 2009.77f. Thesis ( $\mathrm{PhD}$ in Animal Science) - UEM, Universidade Estadual de Maringá, Maringá.

De Jong, D. \& L.S. Gonçalves 1981. The Varroa problem in Brazil. American Bee Journal 121:186-189.

Doolittle, G.M. 1889. Scientific queen-rearing as practically applied. Chicago: Illinois, $163 \mathrm{p}$.

Falconer, D.S. 1987. Introdução a genética quantitativa. Viçosa, MG: UFV, 279p.

Geweke, J. 1992. Evaluating the accuracy of sampling-based approaches to the calculation of posterior moments. Bayesian Stat 4:625-631. 
Gilliam, M., S. Taber \& G.V. Richardson, 1983. Hygienic behavior of honey bees in relation to chalkbrood disease. Apidologie 14:29-39.

Gramacho, K.P. Estudo do comportamento higiênico em Apis mellifera, como subsídio a programas de seleção e melhoramento genético em abelhas. 1995. 103f. Dissertation (Master's degree in entomology). Faculdade de Filosofia, Ciências e Letras de Ribeirão Preto, Ribeirão Preto.

Harbo, J.R. \& J.W. Harris 1999. Heritability in honey bees (Hymenoptera: Apidae) of characteristics associated with resistance to Varroajacobsoni (Mesostigmata: Varroidae). Journal of Economic Entomology 92:262-265.

Heidelberger, P. \& P. Welch 1983. Simulation run length control in the presence of an initial transient. Operations Research 31:1109-1144.

Junkes, L., J.C.V.Guerra Jr. \& G. Moretto 2007. Varroa destructor mite mortality rate according to the amount of worker broods in Africanized honey bee (Apis mellifera L.) colonies. Acta Scientiarum Animal Science 29:305-308.

Lee K.V., R.D. Moon, E.C. Burkness, W.D. Hutchison \& J. Spivak 2010. Practical Sampling Plans for Varroa destructor (Acari: Varroidae) in Apis mellifera (Hymenoptera: Apidae) Colonies and Apiaries. Journal of Economic Entomology 103:1039-1050.

Message, D. 2006. Devemos utilizar produtos quimioterápicos para controlar doenças e parasitoses das abelhas africanizadas? In: Nogueira-Couto, R.H. \& L.A. Couto. Apicultura: manejo e produtos. Jaboticabal: Funep, p.147-156.

Momot, J.P. \& W.C. Rothenbuhler 1971. Behaviour genetics of nest cleaning in honeybees VI. Interactions of age and genotype of bees, and nectar flow. Journal of Apicultural Research 10:11-21.

Moretto, G., L.S. Gonçalves \& D. De Jong 1993. Heritability of Africanized and European honey bee defensive behavior against the mite Varroa jacobsoni. Revista Brasileira de Genética 16:71-76.

Moretto, G., L.S. Gonçalves, D. De Jong \& M.Z. Bichuette 1991. The effects of climate and bee race on Varroa jacobsoni Oud. infestation in Brazil, Apidologie 22:197-203.

Moretto, G. \& L.J. Mello 2001. Infestation and distribution of the mite Varroa jacobsoni in Africanized honey bee (Apis mellifera) colonies. Interciencia 26:394-396.

Morse, R.A. \& L.S. Gonçalves 1979. Varroa disease, a threat to world beekeeping. Bee Culture 107:179-181.

Newton, D.C., G.C. Cantowell \& E.P. Bourquin 1975. Removal of freeze-killed brood as an index of nest cleaning behavior in honeybee colonies (Apis mellifera L.). American Bee Journal 115:388-406.

Nogueira-Couto, R.H. Produção de alimento e cria de colméias de Apis mellifera infestadas com Varroa jacobsoni, em regiões canavieiras. 1991. 131f. Thesis (Livre Docência em Apicultura) - Universidade Estadual Paulista, Faculdade de Ciências Agrárias e Veterinárias, Jaboticabal.

RDevelopment Core Team. 2009. R: A language and environment for statistical computing. R Foundation for Statistical Computing, Vienna, Austria. ISBN 3-900051-07-0, URL http://www.R-project.org. 
Rinderer, T.E. 1977. A new approach to honey bee breeding at the Baton Rouge USDA, Laboratory. American Bee Journal 117:146-147.

Rothenbühler, W.C. 1964. Behaviorgenetics of nest cleaning in honey bees IV. Responses ofF1 and backcross generations to disease-killed brood. American Zoologist 4:111-123.

Spiegelhalter, D.J., A.P. Dawid, S.L. Lauritzen \& R.G. Cowell 1993. Bayesian analysis in expert systems. Statistical Sciences 8:219-283.

Spivak, M. \& D.L. Downey 1998. Field assays for hygienic behavior in honey bees (Hymenoptera: Apidae). Journal of Economic Entomology 91(1):64-70.

Spivak, M. \& M. Gilliam 1993. Facultative expression of hygienic behavior of honey bees in relation to disease resistance. Journal of Apicultural Research 32:147-157.

Stort, A.C., L.S. Gonçalves, O. Malaspina \& F.A. Moura Duarte 1981. Study on sineacar effectiveness in controlling Varroa jacobsoni. Apidologie 12:289-297.

Taber, S. 1982. Bee behavior: Breeding for disease resistance. American Bee Journal 122:823825.

Terada, Y., C.A. Garofalo \& S.F. Sakagami 1975. Age-survival curves for workers of two eusocial bees (Apis mellifera and Plebeia droryana) in a subtropical climate, with notes on worker polytheism in P. droryana. Journal of Apicultural Research 14:161-170.

Toledo, V.A.A. \& G.F. Mouro 2005. Produção de geléia real com abelhas africanizadas selecionadas cárnicas e híbridas. Revista Brasileira de Zootecnia 34:2085-2092.

Toledo, V.A.A. \& R.H. Nogueira-Couto 1996. Infestação de colônias híbridas de abelhas Apis mellifera pelo ácaro Varroa jacobsoni. ARS Veterinária 12:104-112.

Winston, M.L. The biology of the honey bee. London: Harvard University, 1987. 281p.

Winston, M.L.\&S.J.Katz 1981.Longevity of cross-fostered honeybeeworkers (Apismellifera) of European and Africanized races. Canadian Journal of Zoology 59:1571-1574.

Winston, M.L., O.R. Taylor \& G.W. Otis 1983. Some differences between temperate and tropical African and South American honeybees. Bee World 64:12-21.

\section{APPENDIX}

Figures 2-11 begin on page 19 


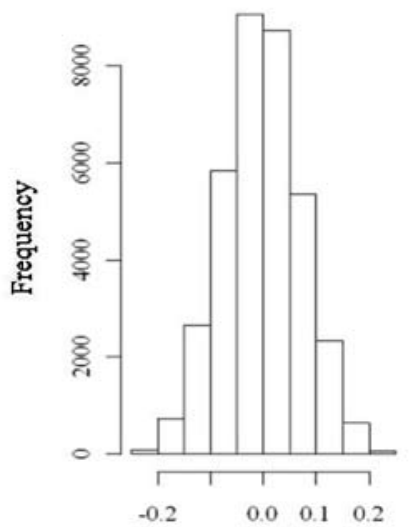

A

Phenotypic correlation

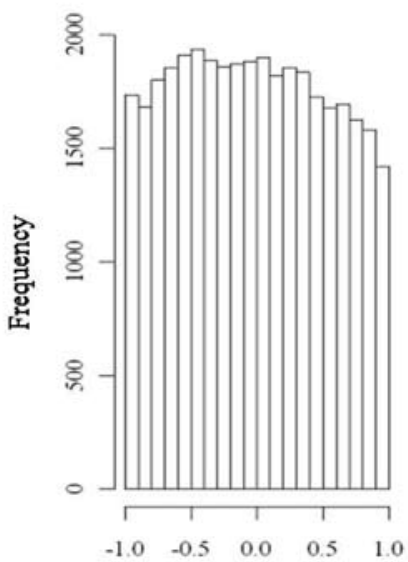

B Genetic correlation

Fig. 2. Phenotypic (A) and genetic (B) correlation of hygienic behavior with infestation rate of the mite Varroa destructor

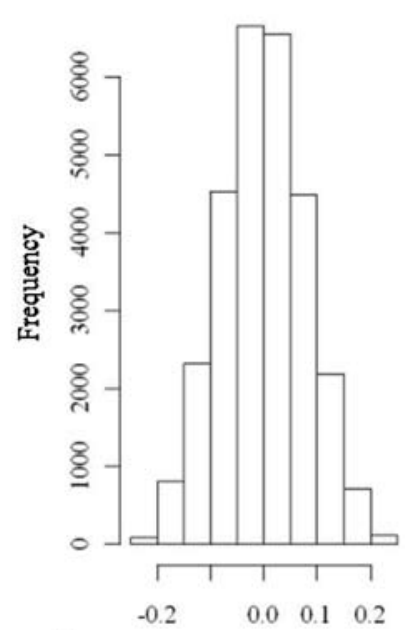

A Phenotypic correlation

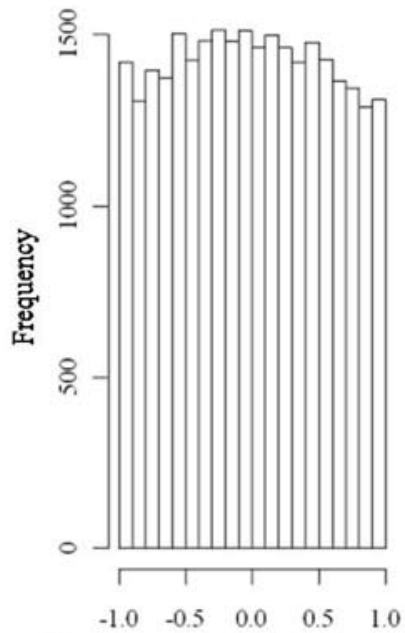

B Genetic correlation

Fig. 3. Phenotypic (A) and genetic (B) correlation of hygienic behavior with invasion rate of the mite Varroa destructor. 


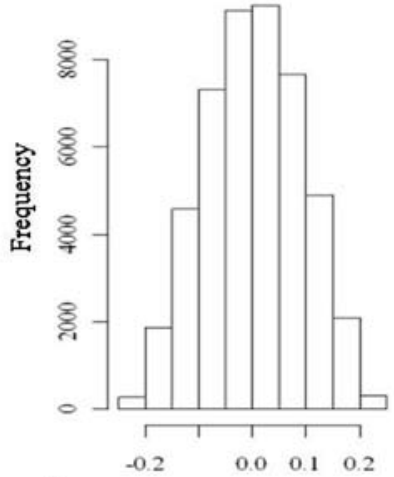

A

Phenotypic correlation

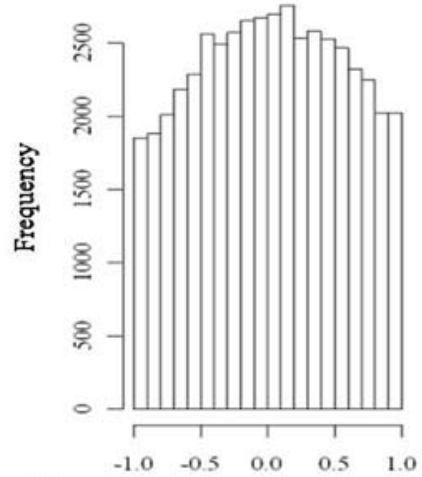

B

Fig. 4. Phenotypic (A) and genetic (B) correlation of hygienic behavior with effective reproduction rate of the mite Varroa destructor.

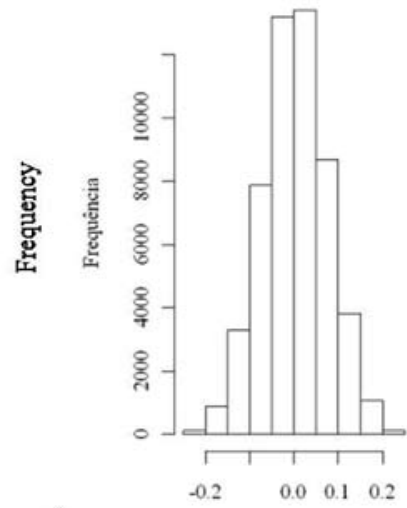

A Phenotypic correlation

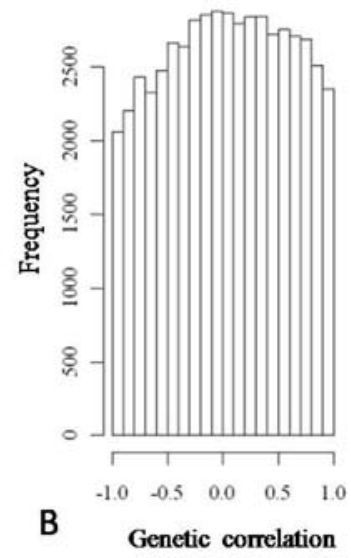

Fig. 5. Phenotypic (A) and genetic (B) correlation of infestation rate and invasion rate of the mite Varroa destructor. 


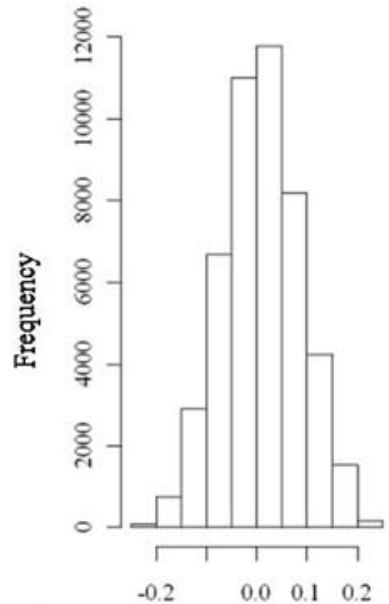

A

Phenotypic correlation

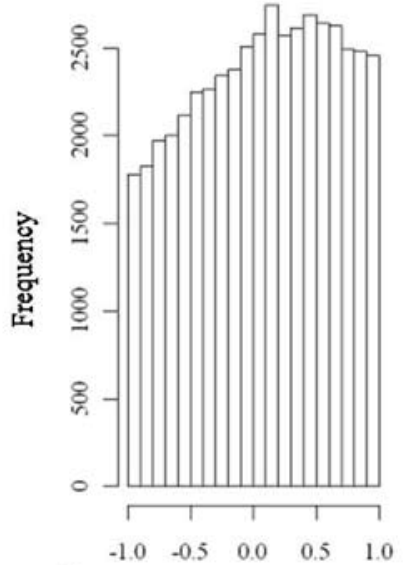

B Genetic correlation

Fig. 6. Phenotypic (A) and genetic (B) correlation of invasion rate and effective reproduction rate of the mite Varroa destructor.

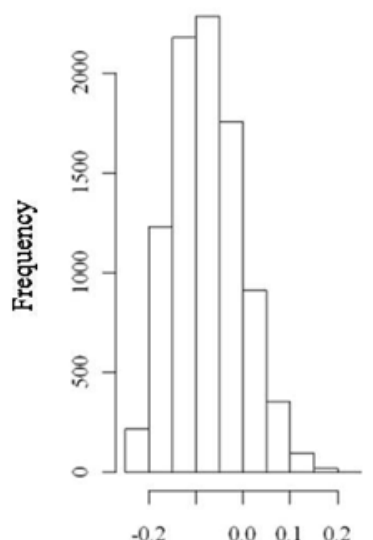

A

Phenotypic correlation

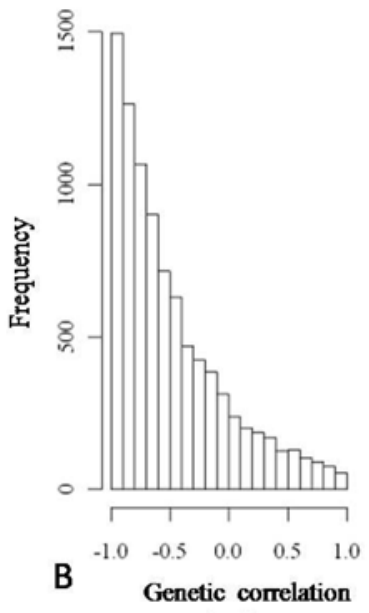

Fig. 7. Phenotypic (A) and genetic (B) correlation of hygienic behavior with total reproduction rate of the mite Varroa destructor. 


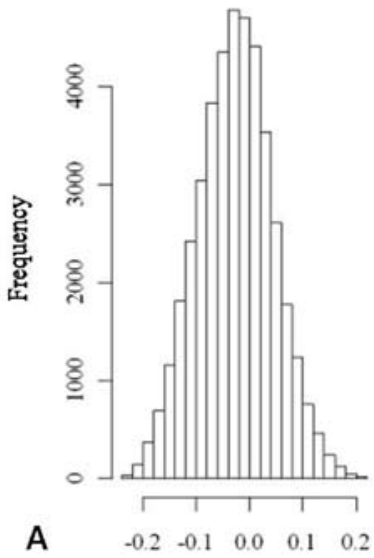

Phenotypic correlation

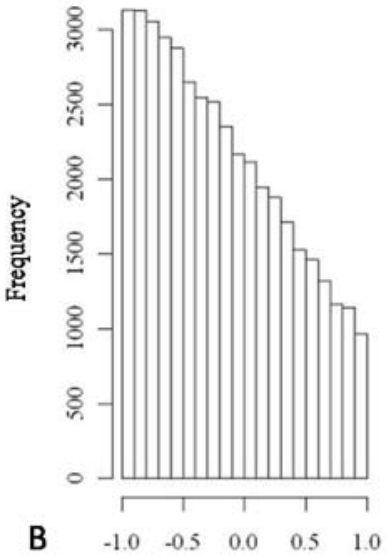

Genetic correlation

Fig. 8. Phenotypic (A) and genetic (B) correlation of infestation rate with total reproduction rate of mite Varroa destructor.

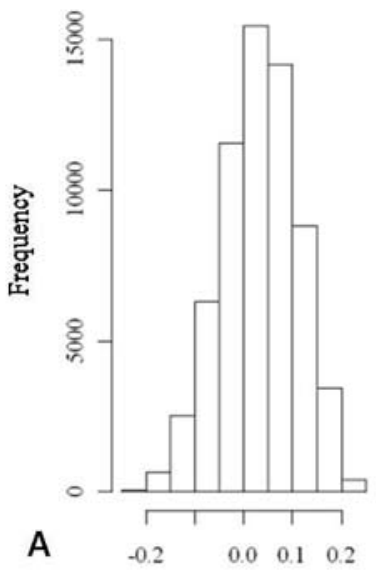

Phenotypic correlation

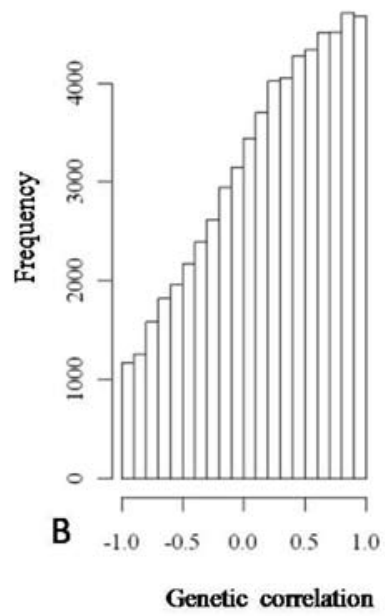

Fig. 9. Phenotypic (A) and genetic (B) correlation of infestation rate with effective reproduction rate of the mite Varroa destructor. 


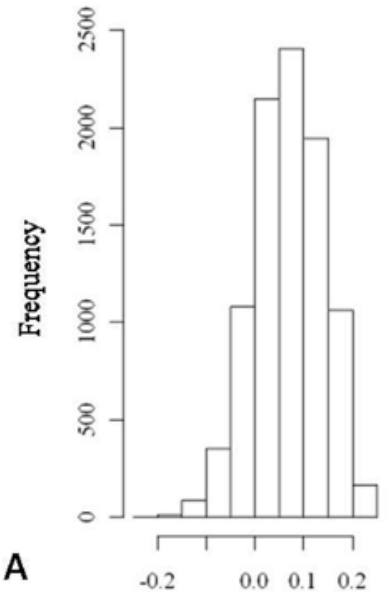

Phenotypic correlation

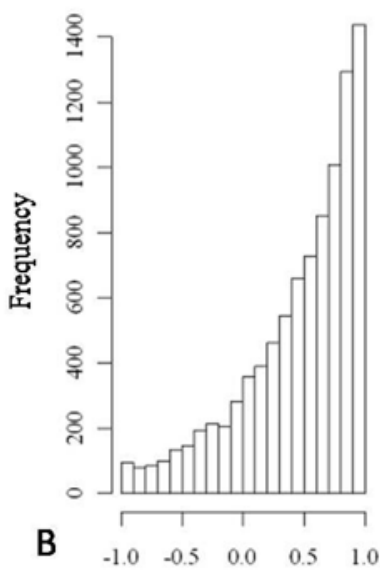

Genetic correlation

Fig. 10. Phenotypic (A) and genetic (B) correlation of invasion rate with total reproduction rate of the mite Varroa destructor.

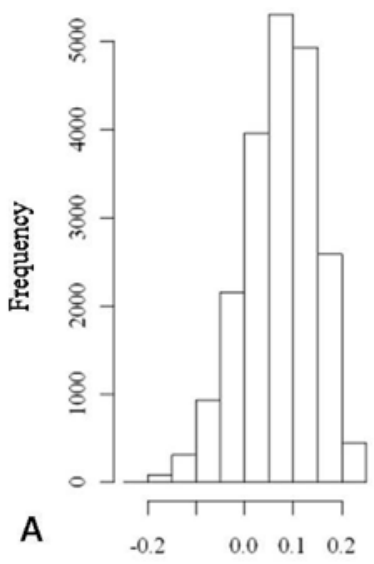

Phenotypic correlation

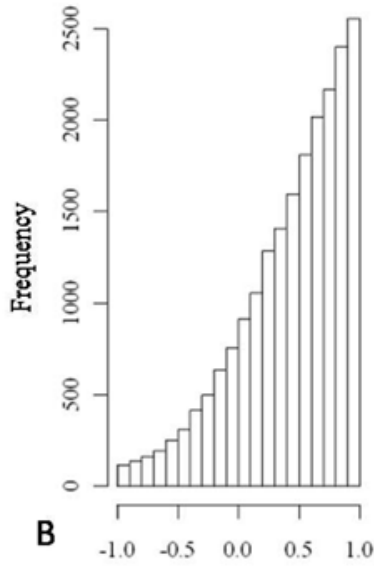

Genetic correlation

Fig. 11. Phenotypic (A) and genetic (B) correlation of total reproduction rate with effective reproduction rate of the mite Varroa destructor. 